INEEL/EXT-99-00325

April 1999

\title{
DISSOLUTION STUDIES WITH PILOT PLANT AND ACTUAL INTEC CALCINES
}

\author{
R. S. Herbst \\ T. G. Garn
}

LOCKHEEDMARTIN 


\title{
Dissolution Studies With Pilot Plant and Actual INTEC Calcines
}

\author{
R. S. Herbst
}

T. G. Garn

Published April 1999

\author{
Idaho National Engineering Laboratory \\ High Level Waste Program \\ Lockheed Martin Idaho Technologies Company \\ Idaho Falls, Idaho 83415
}

Prepared for the

U.S. Department of Energy

Assistant Secretary for Environmental Management

Under DOE Idaho Operations Office

Contract DE-AC07-94ID13223 


\section{ABSTRACT}

The dissolution of INTEC (previously the Idaho Chemical Processing Plant) pilot plant calcines was examined to determine solubility of calcine matrix components in acidic media. Two representative pilot plant calcine types were studied: Run 74 Zirconia calcine and Run 64 Zirconia/Sodium calcine. Dissolution of the calcines were evaluated using lower initial concentrations of nitric acid than used in previous tests to decrease the $\left[\mathrm{H}^{+}\right]$concentration in the final solutions. Lower $\left[\mathrm{H}^{+}\right]$concentrations contribute to more favorable TRUEX/SREX solvent extraction flowsheet performance. Experimental results indicated the following conditions define the baseline dissolution process for $\mathrm{Zr}$ calcine types:

- $3 \mathrm{MHNO}_{3}$

- $10 \mathrm{~mL}$ acid:1 gram calcine ratio

- Temperature $\sim 100^{\circ} \mathrm{C}$ (boiling)

- $\quad$ Time $=1$ hour

Under the above conditions, the final dissolved solutions contained an $\mathrm{H}^{+}$concentration of $\sim 1.2 \mathrm{M}$ while dissolving $>95 \mathrm{wt}$. $\%$ of initial calcine mass. The solution stability adequately met previous calcine dissolution criteria.

Dissolution and analytical results were also obtained for radioactive calcines produced in 1998 during NWCF campaign H-4. This calcine was produced using high sodium feeds from tanks WM-185 and WM-188 blended with non-radioactive $\mathrm{Al}\left(\mathrm{NO}_{3}\right)_{3}$ solutions to dilute the sodium concentration and prevent bed agglomeration during the calcination process. Due to the addition of $\mathrm{Al}\left(\mathrm{NO}_{3}\right)_{3}$, the $\mathrm{H}-4$ calcines composition resemble that of Al types. Dissolution tests indicated $>95 \mathrm{wt}$. $\%$ of the initial calcine mass can be dissolved using the above baseline dissolution procedure, with the exception that higher (5.1 to $5.9 \mathrm{M} \mathrm{HNO}_{3}$ ) initial nitric acid concentrations are required. The higher initial acid concentration is required for stoichiometric dissolution of the oxides, primarily aluminum oxide, $\mathrm{Al}_{2} \mathrm{O}_{3}$.

Statistically designed experiments using Run 74 pilot plant calcine were performed to determine the effect of mixing rate on dissolution efficiency. Three variables were ranked using an interaction analysis to determine the effects of three process variables on the measured response (wt. \% dissolution.) The variables were ranked in order of decreasing effect:

\section{Temperature > Acid/Calcine Ratio > Mixing Rate}

Mixing rate was determined to provide minimal effects on wt. \% dissolution. The acid/calcine ratio and temperature were the predominate variables affecting the wt. \% dissolution, a result consistent with previous studies using other similar types of pilot plant calcines. 


\section{ACKNOWLEDGEMENTS}

The technical input of Tom Batcheller is greatly appreciated. His assistance with the design and operation of the parametric studies experimental setup greatly assisted in providing accurate mixing data.

The authors would also like to thank Natasha Wheatley and Nathan Bronson for their efforts contributing to results obtained for the parametric dissolution studies.

Many thanks are also sent out to the analysts at the RAL and the NWCF operations personnel. Their support with actual NWCF calcine handling was instrumental in the radioactive calcine dissolution experimentation

Without the support and dedication of these people this work would not have been possible. 


\section{CONTENTS}

ABSTRACT .............................................................................................................................II

ACKNOWLEDGEMENTS ............................................................................................... IV

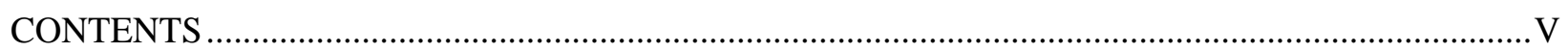

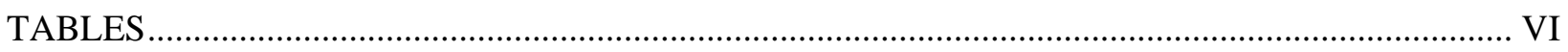

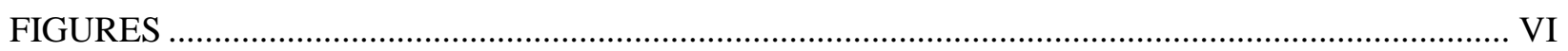

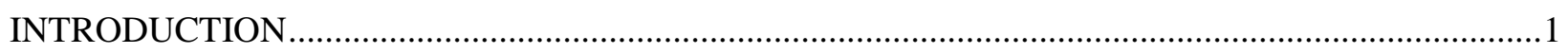

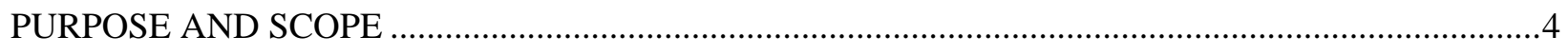

EQUIPMENT DESCRIPTION .................................................................................................

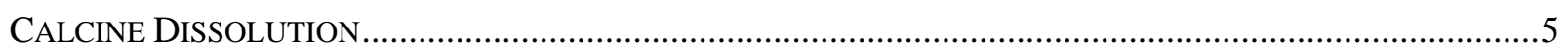

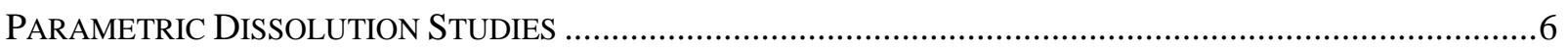

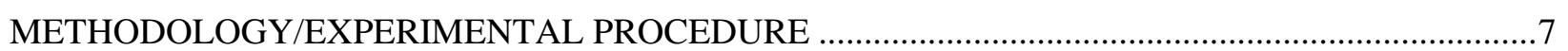

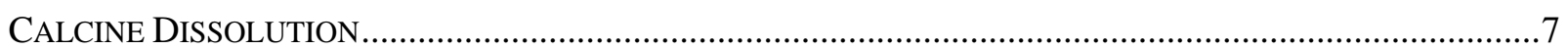

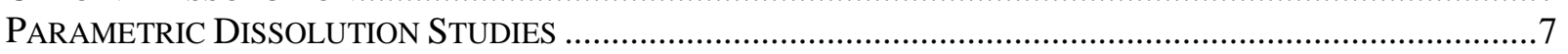

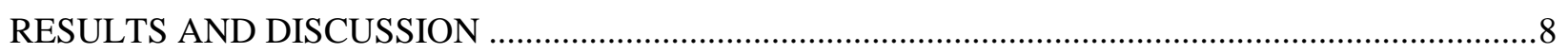

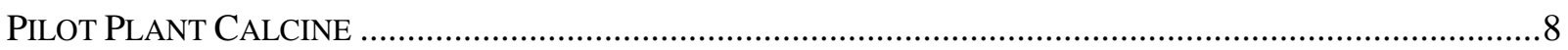

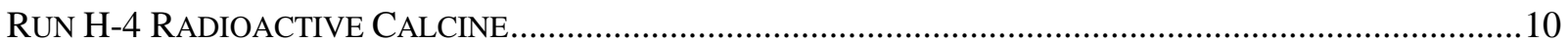

PARAMETRIC DISSOLUTION STUDIES ........................................................................................ 13

CONCLUSIONS AND RECOMMENDATIONS ...........................................................................

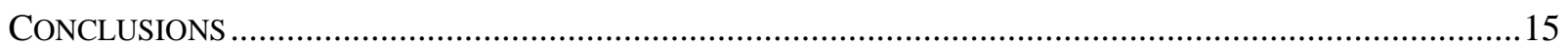

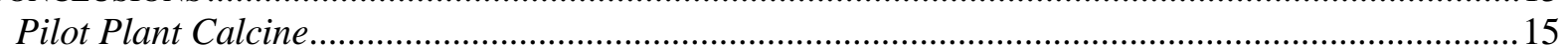

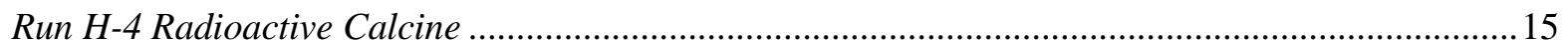

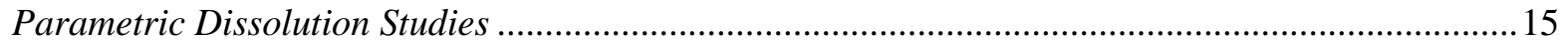

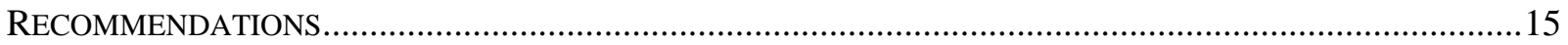

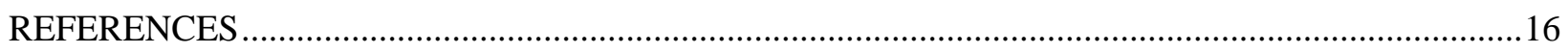

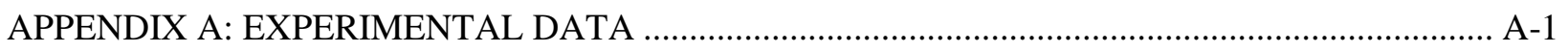




\section{TABLES}

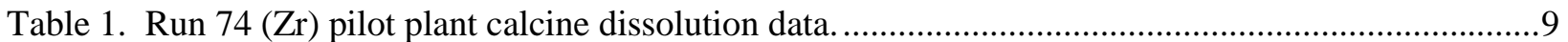

Table 2. Run 64 (Zr/Na) pilot plant calcine dissolution data. ..................................................... 9

Table 3. Estimated calcine and resulting dissolver solution compositions for $\mathrm{H}-4$ calcines....................10

Table 4. Campaign H-4 radioactive calcine dissolution data..................................................11

Table 5. Comparison of estimated and analytical results for dissolved WM-188/ANN calcine..............12

Table 6. Sign nomenclature including variable parameters for statistical experiment..........................13

Table 7. Table of signs illustrating results of dissolution experiments with Run 74 pilot plant calcine....13

Table 8. Statistical analysis of process variable effects on dissolution of Run 74 calcine.......................14

Table A-1. Run 74 pilot plant calcine (single batches). ...................................................... A-2

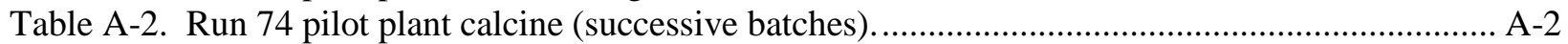

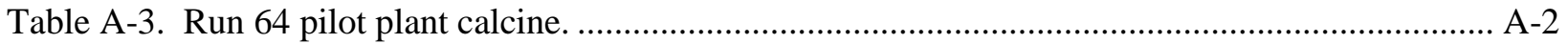

Table A-4. $\left[\mathrm{H}^{+}\right]$and density measurements for various dissolved calcine solutions. ........................ A-2

Table A-5. Dissolution data for actual H-4 NWCF calcine . ................................................... A-3

Table A-6. Weight \% dissolution for parametric dissolution study variables................................ A-3

\section{FIGURES}

Figure 1. Typical pilot plant calcine dissolution experimental setup. ..................................................

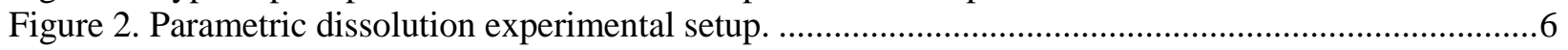




\section{Dissolution Studies With Pilot Plant and Actual INTEC Calcines}

\section{INTRODUCTION}

The Idaho Nuclear Technology \& Engineering Center (INTEC), formerly known as the Idaho Chemical Processing Plant (ICPP) reprocessed spent nuclear fuels from defense and other government owned reactors for the recovery of fissionable uranium. Raffinates from the PUREX-type process where subsequently solidified into solid, granular calcine and stored onsite in near surface stainless steel bins encased in concrete vaults. In the head-end fuel dissolution process, the fuel and cladding were completely dissolved; consequently, the bulk of the reprocessing raffinates were comprised of inert matrix materials with trace quantities of the transuranic (TRU) elements, fission products (predominately ${ }^{137} \mathrm{Cs}$ and ${ }^{90} \mathrm{Sr}$ ), and fission product lanthanides. The product from subsequent solidification of the raffinates is a stable blend of metal oxides containing the bulk, inert matrix components and less than 1 weight $\%$ of the radioactive constituents [1]. Although the mass fraction of the radionuclides in these calcines is quite low, the solids are intensely radioactive.

A secondary liquid waste was also generated during reprocessing activities from equipment decontamination and process solvent cleanup processes. This acidic secondary waste is referred to as sodium bearing waste (SBW), due to the high sodium content, and was temporarily stored separately from liquid reprocessing raffinates. Due to the high sodium content, the SBW is not amenable to calcination directly; rather, it was historically blended with fuel reprocessing raffinates in various proportions prior to calcination. Blending is no longer an option since all raffinate solutions have subsequently been depleted.

It is anticipated that the calcine will be treated prior to permanent disposal in a geological repository. One option being evaluated at INTEC is the dissolution of calcines and subsequent separation unit operations to partition and concentrate the small fraction of radionuclides from the bulk inert constituents. The resulting high activity waste (HAW) fraction would be vitrified into a stable waste form for permanent disposal and the larger volume of low level waste (LLW) would be immobilized for near surface disposal.

Currently, several distinctive types of calcine are stored in the INTEC bin sets, including alumina, zirconium, zirconium/sodium blend, aluminum/sodium blend, aluminum/zirconium/sodium blend, stainless steel, and non-radioactive alumina/dolomite startup bed material. The particular type of calcine is associated with the type of clad material used in the reprocessed fuel. Each of these different calcine types represents a chemically different feed stream to the proposed waste isolation facility and the calcine dissolution unit operation.

Experimental work on calcine dissolution was performed in FY93 and FY94 using simulated calcines generated in the pilot plant calciners at INTEC [2]. The analysis of undissolved solids (UDS) from the dissolution of pilot plant calcines indicate the major undissolved species are $\alpha$ - and $\gamma$-alumina (both phases are insoluble in mineral acids) for $\mathrm{Al}$ containing calcines and $\mathrm{CaF}_{2}$ or calcium stabilized zirconia, $\mathrm{Ca}_{0.15} \mathrm{Zr}_{0.85} \mathrm{O}_{1.85}$, for the $\mathrm{Zr}$ type calcines. Based on this information, it is assumed that these species will constitute the bulk of the UDS regardless of calcine type. In the case of the three-way blends, all of the insoluble species may exist, for $\mathrm{Zr}$ calcine types, the $\mathrm{CaF}_{2}$ and $\mathrm{Ca}_{0.15} \mathrm{Zr}_{0.85} \mathrm{O}_{1.85}$ will predominate, and in the $\mathrm{Al}$ calcines, the insoluble $\alpha$ - and $\gamma$ - phases of $\mathrm{Al}_{2} \mathrm{O}_{3}$ will be the major contributor to the UDS. Consequently, dissolution studies focus primarily on the $\mathrm{Al}$ and $\mathrm{Zr}$ calcine types, since these calcines represent the extreme cases of required dissolution conditions; the other blend type calcines are anticipated to fall within this regime for dissolution of the currently stored calcines. A primary strategy of the 
dissolution program involves validation of this assumption by testing the dissolution parameters developed during this study on the other types of calcines and verification of the results on samples of the actual calcines.

The previous experimental work with pilot plant calcines focussed on definition of dissolution parameters for five different, representative types of pilot plant calcine [2]. The goal of that work was to establish a single dissolution procedure applicable to the gamut of calcine types with the objectives of dissolving the maximal amount of calcine with minimal processing requirements in terms of dissolvent (acid) composition and amount used, process time, and temperature. The suggested "baseline" dissolution process resulting from that work was $10 \mathrm{~L}$ of $5 \mathrm{M} \mathrm{HNO}_{3}$ per $\mathrm{kg}$ of calcine at a temperature of $\geq 90^{\circ} \mathrm{C}$ for 30 minutes with constant, vigorous mixing. In all but one case, these conditions resulted in $>90 \mathrm{wt}$ \% dissolution of the calcine and a final dissolver solution acidity of 2.4 to $3.7 \mathrm{M} \mathrm{H}^{+}$. The exception to this case was the Alumina (Al) pilot plant calcine (Run 1027), for which only 51.3 wt. \% dissolved. Analysis of the UDS from the Run 1027 calcine indicated the major species was insoluble $\gamma-\mathrm{Al}_{2} \mathrm{O}_{3}$. The Run 1027 calcine is the only pilot plant $\mathrm{Al}$ calcine type available for development testing. Small amounts of boron $\left(0.01 \mathrm{M} \mathrm{H}_{3} \mathrm{BO}_{3}\right)$ were historically added to alumina raffinate to inhibit formation of the insoluble $\mathrm{Al}$ phases during the calcination process [3]. A parametric study associated with two of the pilot plant calcines indicated the main effects on weight percent dissolution were ranked in the order:

\section{Acid/Calcine Ratio > Temperature $>\mathrm{HNO}_{3}$ Conc. $>$ Dissolution Time}

The effects of mixing on percent dissolved were not included in that study [2].

It is of importance to note that there is limited dissolution data on actual Al calcine produced in the Waste Calcining Facility (WCF) during early campaigns [4,5]. These data indicate that 293 to 99 wt. \% of actual $\mathrm{Al}$ calcine can be dissolved in nitric acid. Given the amount of $\mathrm{Al}$ type calcine that must be processed and the effects reduced dissolution can have on process performance, it is imperative that these results be validated with actual samples of this calcine and that the appropriate analyses be performed on the resulting UDS and dissolved solutions. This information is mandatory to evaluate the dissolution process, provide valuable material balance data, and necessary information to determine if the downstream operations are to perform effectively.

Dissolution experiments were performed in FY94 and FY95 with two types of actual calcines produced in the New Waste Calcination Facility (NWCF) during campaign H-3 [6,7]. One of the calcines was an Alumina type, albeit non-representative of the early material produced in WCF since the Al liquid waste was very dilute. During the campaign, boric acid was added to inhibit formation of insoluble Al phases, and calcium nitrate was added to increase the dissolved solids content in the feed to the calciner. Consequently, this calcine contained a much higher weight percentage of calcium and much less aluminum than would be typical for the earlier Al calcine. The dissolution data for the $\mathrm{Al}$ calcine used in that test indicated that up to $96 \mathrm{wt}$. \% of the calcine was dissolved under the conditions of the baseline dissolution process, except with an increase in dissolution time from 30 minutes to 24 hours. The UDS contained $\mathrm{Al}_{2} \mathrm{O}_{3}$ as the major constituent and $\mathrm{CaF}_{2}$ as a minor component. A Zirconium type calcine was also produced in NWCF during the H-3 campaign. This $\mathrm{Zr}$ type calcine was produced from 3.5 parts zirconium (Fluorinel) raffinate and one part sodium waste, resulting in a $\mathrm{Zr} / \mathrm{Na}$ two-way blend. This calcine is also somewhat atypical of $\mathrm{Zr} / \mathrm{Na}$ blends since boric acid and calcium nitrate were added to the feed (for the reason mentioned previously), and the waste also contained more aluminum than usual. Using the baseline dissolution procedure, 95 to $98 \mathrm{wt}$ \% of this calcine was dissolved and the major constituents of the UDS were $\alpha-\mathrm{Al}_{2} \mathrm{O}_{3}$ and stabilized zirconium oxides. In the case of both calcine types, the UDS contained sufficient quantities of radionuclides to preclude their disposal as low level waste.

Dissolved calcine solutions prepared by the dissolution of zirconium (Run 74) pilot plant calcine were used for the early development work with the TRUEX actinide separation process [8]. The dissolved Run 74 calcine solutions were prepared with baseline dissolution parameters mentioned previously. These 
experimental data indicated numerous problems associated with the rather high (anticipated worst case) zirconium concentration of $\sim 0.21 \mathrm{M} \mathrm{Zr}$ in the dissolved calcine solution. Apparently, the extraction of $\mathrm{Zr}$ by the solvent was so severe that the organic phase was saturated with zirconium, resulting in suppressed actinide (primarily $\mathrm{Am}^{3+}$ ) distribution coefficients, third phase formation, interfacial crud, and numerous other problems encountered in the different sections of the TRUEX flowsheet. Suppressed actinide distributions and massive $\mathrm{Zr}$ extraction were also noted in batch contacts with the TRUEX solvent and the dissolved solution of NWCF H-3 Zr type calcine from the dissolution discussed above. A great deal of development effort was expended on defining adjustments to the TRUEX flowsheet and on the calcine dissolution parameters to compensate for $\mathrm{Zr}$ extraction and the concomitant problems. Preliminary data indicate alteration of the dissolution parameters to obtain a lower $\mathrm{H}^{+}$concentration in the final dissolver product enhances the extraction distribution coefficients of the actinides, presumably due to a reduction in $\mathrm{Zr}$ and/or acid extraction. As a result of this data, the baseline $\mathrm{Zr}$-type calcine dissolution procedure has been revisited in order to enhance the efficiency of the TRUEX actinide separation process. It is important to note that continued efforts to refine the dissolution process would revolve around providing a suitable feed for all of the downstream separations processes, not only for actinide separations, but for the strontium and cesium separations as well. 


\section{PURPOSE AND SCOPE}

The purpose of this work was to define a calcine dissolution procedure to produce a dissolved product that would enhance the efficiency of the downstream separation processes, primarily the TRUEX process for actinide separations [8,9]. Preliminary work indicated lowering the acid concentration in the dissolved calcine solution (the dissolver product) would dramatically improve the performance of the TRUEX process. Consequently, the scope of this work focussed on altering the baseline dissolution process to produce a product with lower acidity without impacting the dissolution efficiency or stability of the dissolver product with regard to precipitate formation.

Previous statistical experiments were performed to determine the main effects associated with wt. \% dissolution of various pilot plant calcine types. The acid/calcine ratio effect was determined to have the most significant impact on the weight percentage of calcine dissolved. The scope of this work also included a statistical determination of the importance of mixing effect on dissolution efficiency for Run 74 calcine. Earlier data suggests mixing rate could play a vital role in reaction kinetics, as opposed to diffusion for rate limiting reactions.

The baseline calcine dissolution procedure called for a ratio of $10 \mathrm{~mL} 5 M \mathrm{HNO}_{3}$ acid/ gram calcine at a temperature $>90^{\circ} \mathrm{C}$ for a dissolution time of 30 minutes, resulting in $>90 \mathrm{wt}$. \% dissolution of the initial calcine mass. The final dissolved solution $\left[\mathrm{H}^{+}\right]$concentration was $\sim 3.4 M$ and the density was $\sim 1.2 \mathrm{~g} / \mathrm{mL}$. The resulting solution did not exhibit instability with regard to the formation of precipitates. Numerous trials at altering the dissolvent recipe were investigated including the addition of various concentrations of $\mathrm{HF}$ in $\mathrm{HNO}_{3}$ acid and increasing the nitrate concentration with soluble aluminum nitrate or sodium nitrate salts, to increase the salting strength in the dissolved calcine solutions. The addition of even small quantities of HF in the dissolvent dramatically reduced the amount of calcine dissolved, and as the concentration of HF was increased, the dissolution efficiency decreased. The addition of aluminum or sodium nitrate to the nitric acid dissolvent also decreased the dissolution efficiency. This study focussed primarily on a reduction of the initial nitric acid concentration in the dissolvent, resulting in lower acid concentration in the dissolver product while adjusting the other dissolution parameters to maintain high dissolution efficiency.

Efforts to define altered dissolution parameters were directed toward simulated $\mathrm{Zr}$ calcine produced in the INTEC pilot plant calciner. These pilot plant calcines were produced during development efforts supporting NWCF flowsheets. The calcine used for dissolution testing is designated as Run 74 pilot plant calcine. The newly developed dissolution parameters were subsequently tested on a simulated $\mathrm{Zr} / \mathrm{Na}$ coprocessing calcine simulant denoted as Run 64 pilot plant calcine. Various quantities of the Run 64 and Run 74 calcines were dissolved, not only to verify the dissolution procedure, but also to provide aqueous feed stock for the Strontium Extraction (SREX) and TRUEX development efforts. The Run 64 calcine was selected for SREX development efforts because it contains less stable strontium than the Run 74 calcine.

Finally, the scope of this project included verification of the dissolution parameters on samples of radioactive calcine produced during early 1998 during NWCF campaign H-4. Approximately 200 grams of the H-4 calcine was received in the Remote Analytical Laboratory (RAL) hot cell from the NWCF for dissolution testing. As part of the dissolution experiments, samples of the dissolved calcine solution were analyzed, as were a small sample of the residual UDS. The results of these analyses are included in this report. 


\section{EQUIPMENT DESCRIPTION}

\section{Calcine Dissolution}

Calcine dissolution experiments incorporated the use of glass dissolution vessels, modified to accept a reflux condenser, a calcine addition port and a thermocouple sleeve, designed to extend into the liquid dissolvent. The condenser in the top of the vessel used cooling water to prevent evaporation and maintain approximately constant volume liquid heating. A Fluke 52 type $\mathrm{K} / \mathrm{J}$ thermocouple with LCD display was used to monitor temperature of the dissolution process. Several different sized dissolution vessels were built, including $200 \mathrm{~mL}, 250 \mathrm{~mL}, 1 \mathrm{~L}$, and $4 \mathrm{~L}$ volumes. The dissolution vessels were placed on a Corning stirrer/hotplate and used in conjunction with magnetic stir bars for heating and mixing. The four liter dissolution apparatus used during dissolution experiments with pilot plant calcine is shown assembled in the laboratory fume hood in Figure 1.

A one liter dissolution vessel was utilized for the dissolution experiments performed in the RAL hot cell using similar equipment as described for pilot plant calcine dissolution. The dissolution apparatus was completely contained in the hot cell to provide the necessary protection from the radioactivity associated with the actual calcine.

Filtration and quantitative recovery of the undissolved solids (UDS) remaining after the dissolution process was required to quantify the efficiency of the dissolution process, expressed as weight percentage of the initial calcine mass which dissolved. UDS filtration was effected by using $500 \mathrm{~mL}^{\mathrm{N} A L G E N E}{ }^{\circledR}$ brand disposable filter units containing an $0.47 \mathrm{~mm}$ diameter, $0.45 \mu \mathrm{m}$ pore size cyanonitrile filter membranes or magnetic filter units equipped with replaceable Millipore $0.45 \mu \mathrm{m}$ pore size filter membranes in conjunction with a vacuum pump. Both types of filters were used during the dissolution tests with pilot plant calcines; the disposable NALGENE ${ }^{\circledR}$ units were used exclusively in the dissolution experiments performed in the RAL with actual calcine samples.

Figure 1. Typical pilot plant calcine dissolution experimental setup.

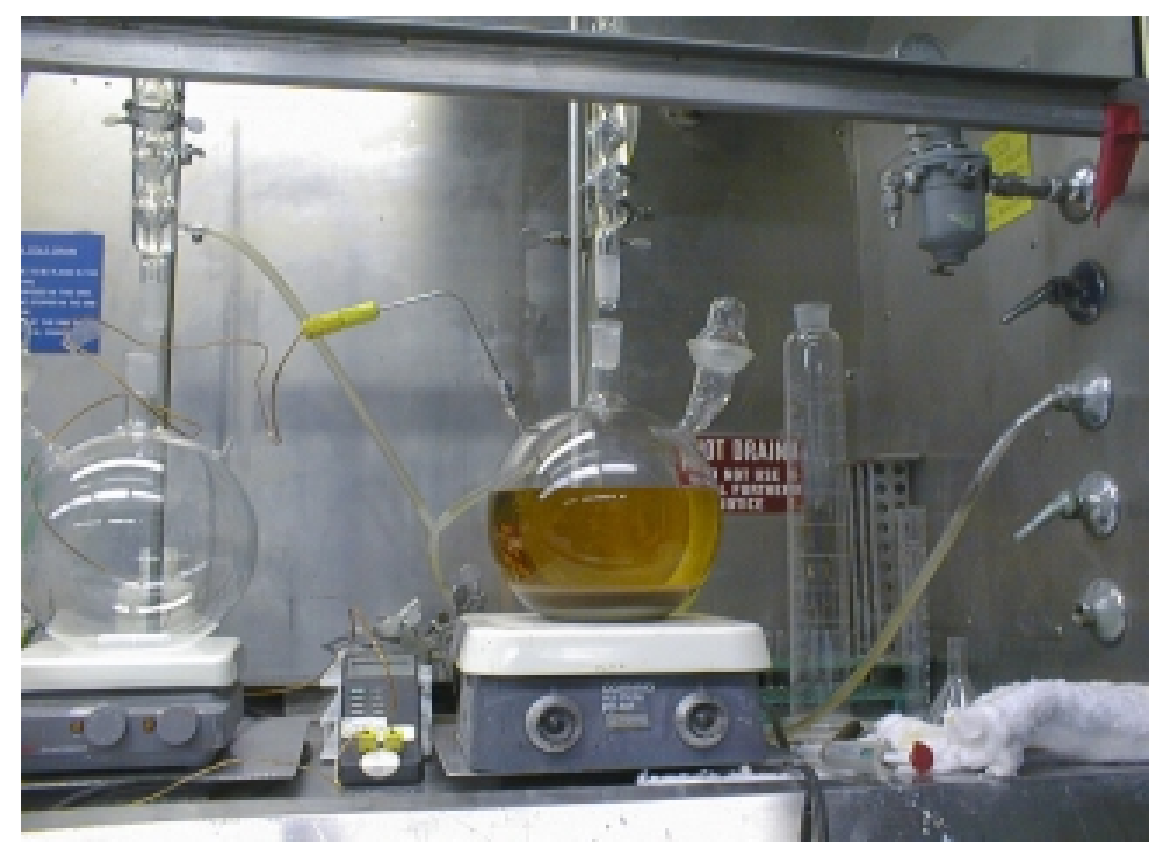




\section{Parametric Dissolution Studies}

The parametric dissolution studies were performed using a dissolution vessel comprised of a baffled 1 L cylindrical glass beaker. The baffles provided more thorough mixing of the dissolvent and calcine during the dissolution. A $1 / 30^{\text {th }}$ hp LIGHTNIN $^{\circledR}$ LabMaster $^{\text {TM }}$ SI mixer (Model L1U03) was used to drive a $1-7 / 8$ " diameter four bladed impeller $\left(45^{\circ}\right.$ pitch) for mixing. The mixer unit enabled a tightly controlled mixing rate from 0-500 rpm, which greatly enhanced studies associated with mixing effects on weight $\%$ calcine dissolved. The lid was fabricated from Teflon and modified for attachments, including a thermocouple, impeller shaft, and a reflux condenser. A Corning hotplate provided heating capabilities. The parametric dissolution experimental setup is shown in Figure 2.

Figure 2. Parametric dissolution experimental setup.

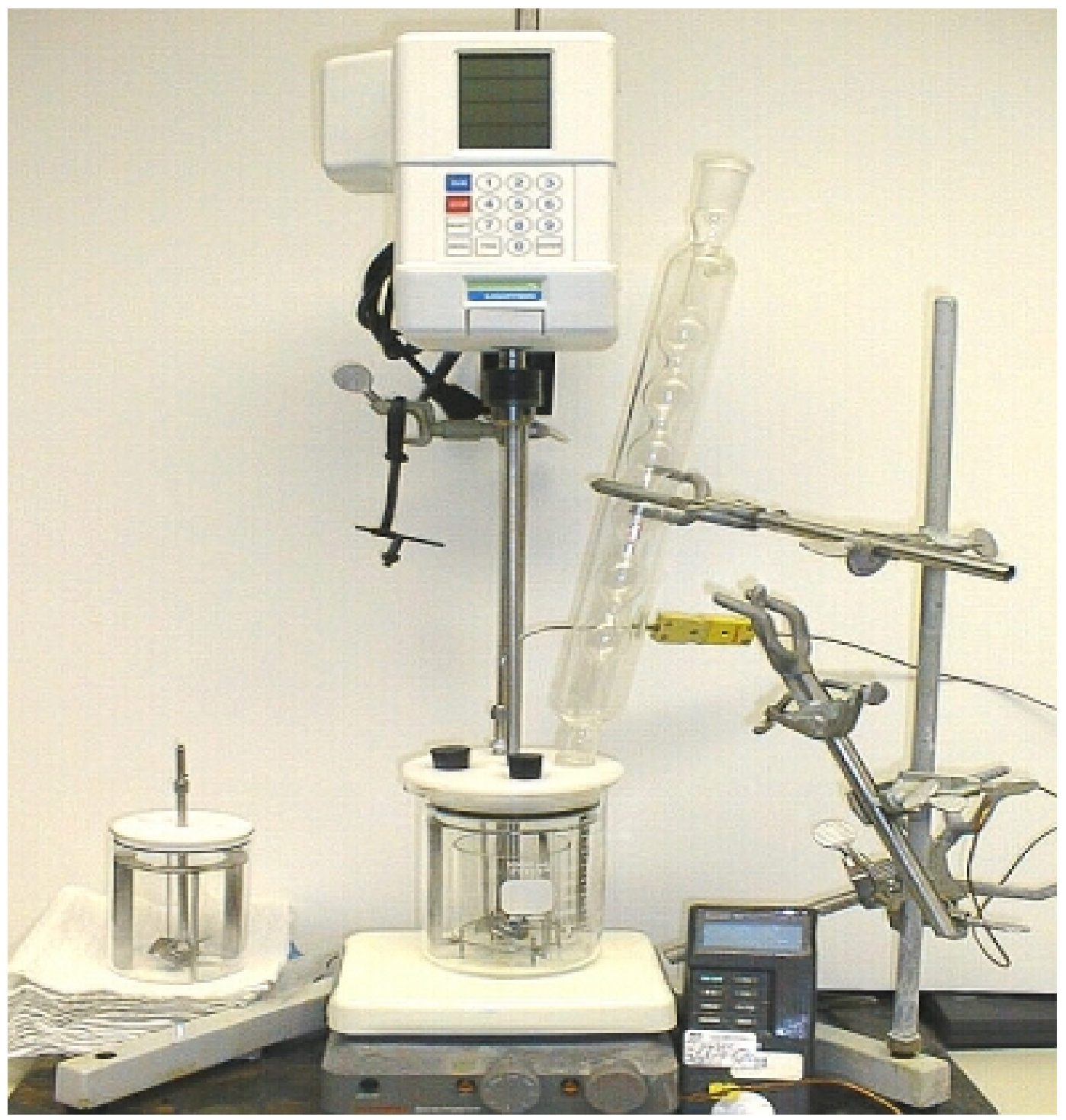




\section{METHODOLOGY/EXPERIMENTAL PROCEDURE}

\section{Calcine Dissolution}

follows:

The experimental procedure developed and used for the calcine dissolution experiments is outlined as

(1) The appropriate initial mass of calcine was accurately weighted on an analytical balance and the weight recorded.

(2) The proper volume of a specified nitric acid concentration was measured to obtain the prescribed acid volume to calcine mass ratio.

(3) Approximately 90 volume $\%$ of the $\mathrm{HNO}_{3}$ was added to the dissolution vessel. The condenser cooling water flow was initiated and the acid was preheated to an initial temperature of $\sim 60^{\circ} \mathrm{C}$ before calcine was added. The calcine was then added to the dissolver followed by the remaining quantity of acid.

(4) Stirring, via the magnetic stir bar, was initiated as per the desired dissolution conditions and the mixture was heated to the desired temperature. The hotplate was used to maintain the desired temperature, which was monitored with the thermocouple and associated electronics. Experiments in the $4 \mathrm{~L}$ vessel required the use of insulation wrapped around the dissolver to obtain elevated (boiling) dissolution temperatures. Time zero was initiated when the vessel reached the prescribed dissolution temperature. Once the prescribed dissolution time was achieved, the solution was allowed to cool and the undissolved solids were gravity settled.

(5) The dissolved solution was then poured onto a pre-weighed filter assembly under vacuum where the UDS were collected for weight determination. During experiments with pilot plant calcine, the filter and solids were air-dried. During the dissolutions in the RAL hot cell, a small volume (10 $20 \mathrm{~mL}$ ) of propanol was poured through the solids and filter to facilitate the drying process.

(6) The dried filter and solids were accurately weighted to determine the residual UDS mass. The UDS and initial calcine weights were used to determine weight percent dissolved according to the following equation:

Weight \% Dissolved $=[1-\text { UDS Wt. (g)/Initial Calcine Wt. }(\mathrm{g})]^{*} 100 \%$

\section{Parametric Dissolution Studies}

The general dissolution procedure developed and used during the parametric dissolution studies is outlined below:

(1) A predetermined mass of the Run 74 pilot plant calcine was accurately weighed using an analytical balance. The initial calcine weight was recorded.

(2) A predetermined volume of $3 \mathrm{MHNO}_{3}$ was added to the baffled dissolution vessel and heated to a desired temperature. The weighed calcine mass was added to the baffled dissolution vessel with the heated $\mathrm{HNO}_{3}$ acid.

(3) The mixer rate was adjusted to the desired rpm. Dissolution time initiated once the temperature reached the prescribed value and the dissolution allowed to proceed under the prescribed conditions of mixing and temperature for approximately 1.5 hours.

(4) After 1.5 hours, the slurry was poured into a pre-weighed filter unit to separate the UDS from the dissolved solution. The solids were allowed to air dry, and were then weighed to determine the UDS mass. The known mass of calcine added to the system along with the UDS weight values were then used to calculate percent dissolution as per equation (1).

(5) The final dissolved solutions were titrated to a phenopthalein endpoint using standardized sodium hydroxide to determine $\left[\mathrm{H}^{+}\right]$concentration. The density of the final dissolved solution was also measured by accurately weighing $1 \mathrm{~mL}$ of the final dissolver product. 


\section{RESULTS AND DISCUSSION}

\section{Pilot Plant Calcine}

The baseline dissolution procedure propagated from earlier experimental results required $10 \mathrm{~mL}$ of 5 $M \mathrm{HNO}_{3}$ per gram of calcine at a dissolution temperature of $>95^{\circ} \mathrm{C}$ for 30 minutes to dissolve $>90 \mathrm{wt}$. \% of the initial calcine mass [2]. The resulting dissolver solution contained an acid concentration of $\sim 3.4 \mathrm{M}$ $\mathrm{H}^{+}$. This information indicates approximately 0.016 moles of acid are consumed per gram of calcine initially added to dissolution vessel under these conditions. The simplest procedure to produce a liquid dissolution product of lower final acid concentration, in the range of 1 to $1.5 \mathrm{M} \mathrm{H}^{+}$, is to lower the initial acid concentration in the dissolvent. Based on available information, $3 M \mathrm{HNO}_{3}$ as the dissolvent should produce a final product containing 1 to $1.5 \mathrm{M} \mathrm{H}^{+}$using an acid to calcine ratio of $10 \mathrm{~mL} \mathrm{HNO}_{3}$ per gram of calcine:

Final $\left[\mathrm{H}^{+}\right]=\left[3 \mathrm{M} \mathrm{H}^{+}-\left(0.016\right.\right.$ mole $\mathrm{H}^{+} / \mathrm{g}$ calcine $)\left(1 \mathrm{~g}\right.$ calcine $/ 0.01$ mole $\mathrm{H}^{+}$consumed $\left.)\right]=1.4 M \mathrm{H}^{+}$

Alternatively, using an initial acid concentration of $5 \mathrm{MHNO}_{3}$ at an initial acid to calcine ratio of 6 $\mathrm{mL} \mathrm{HNO}_{3}$ per gram of calcine and diluting the final solution from $6 \mathrm{~mL}$ to $10 \mathrm{~mL}$ should also produce a dissolver product with an acid concentration in the desired range:

$$
\begin{gathered}
\text { Final }\left[\mathrm{H}^{+}\right]=\left[\left(5 \mathrm{MH}^{+}\right)(0.006 \mathrm{~L} \text { acid/g calcine })-\left(0.016 \mathrm{~mole} \mathrm{H}^{+} \text {consumed/g calcine }\right)\right] \\
*(1 \mathrm{~g} \text { calcine } / 0.01 \mathrm{~mL} \text { solution })=1.4 \mathrm{M} \mathrm{H}^{+}
\end{gathered}
$$

The concern with either of these dissolution scenarios being that the dissolution efficiency, measured by the weight percentage of calcine dissolved, is not compromised. Consequently, both conditions were experimentally tested with Run 74 pilot plant calcine; however, the dissolution time and the dissolution temperature were varied to evaluate the effects on dissolution efficiency. The results of these experiments with the Run 74 pilot plant calcine are listed in Table 1. It is important to note the earlier experiments which resulted in the baseline dissolution process where conducted in covered beakers, which likely resulted in evaporative losses (volume decrease of the dissolver solution) during the dissolution process. Using the current experimental setup, which includes a condenser, dramatically decreases the potential for evaporative losses and allows the use of boiling temperatures for extended periods of time without significant volume reduction of the liquid dissolver product. Note that the results for experiments \#5 through \#7 are representative of performing five consecutive dissolution batches. In the consecutive batch dissolution tests, the dissolver solution was decanted from the dissolution vessel, leaving the UDS and a small volume of the dissolver product. Fresh calcine and acid were added with the UDS and the process repeated. This cycling of the UDS can be performed numerous times, and the number of consecutive batches are indicated for the experiments listed in Table 1. In the multiple dissolution batches, the weight percent dissolved is based on the total UDS remaining at the end of the test and the total amount of calcine added during each batch. The density and acid concentration of the dissolver product is based on the combined, composite solution from all batches. Two methods of providing mixing were explored; in one case aggressive mixing with a magnetic stir bar was used at a temperature just under the boiling point of the solution, and in the other case boiling the solution at $\sim 100^{\circ} \mathrm{C}$ provided agitation. Finally, the data listed for the baseline (experiment \#1) represents an average based on four separate dissolution experiments using multiple, consecutive batches (ranging from 2 to 12) in each experiment.

The data presented in Table 1 clearly indicate the amount of calcine dissolved under the proposed conditions is comparable, but slightly less, than that achieved with the baseline dissolution parameters. Furthermore, the desired acid concentration in the liquid dissolver product is within the specified range of 1 to $1.5 \mathrm{M} \mathrm{H}^{+}$. The single batch dissolution results for experiments 2 through 4 indicate increased dissolution time facilitates measurable increases in the amount of calcine dissolved. The results from the 
Table 1. Run 74 (Zr) pilot plant calcine dissolution data.

\begin{tabular}{ccccccccc}
\hline Experiment & $\begin{array}{c}\text { Initial } \\
\text { Acid } \\
(\mathrm{M})\end{array}$ & $\begin{array}{c}\text { Acid to } \\
\text { Calcine } \\
(\mathrm{mL} / \mathrm{g})\end{array}$ & $\begin{array}{c}\text { Wt. \% } \\
\text { Dissolved }\end{array}$ & $\begin{array}{c}\text { Final Acid } \\
(\mathrm{M})\end{array}$ & $\begin{array}{c}\text { Density } \\
(\mathrm{g} / \mathrm{mL})\end{array}$ & $\begin{array}{c}\text { Dissolution } \\
\text { Temp. } \\
\left({ }^{\circ} \mathrm{C}\right)\end{array}$ & $\begin{array}{c}\text { Dissolution } \\
\text { Time } \\
(\text { minutes })\end{array}$ & $\begin{array}{c}\text { Mixing } \\
\text { Method }\end{array}$ \\
\hline \#1 Baseline & 5 & $10 / 1$ & 98.5 & 3.10 & 1.21 & $>95$ & 30 & $\begin{array}{c}\text { Stir bar } \\
\text { \#2 Single Batch }\end{array}$ \\
3 & $10 / 1$ & 91.2 & ND & ND & $>95$ & 60 & Stir bar \\
\#3 Single Batch & 3 & $10 / 1$ & 93.6 & 1.10 & 1.17 & $>95$ & 120 & Stir bar \\
\#4 Single Batch & 3 & $10 / 1$ & 95.7 & 1.10 & 1.2 & $>95$ & 360 & Stir bar \\
\#5 Five Batches & 3 & $10 / 1$ & 95.0 & ND & ND & $>95$ & 60 & Stir bar \\
\#6 Five Batches & 5 & $6 / 1$ & 96.6 & 1.17 & 1.11 & $>95$ & 60 & Stir bar \\
\#7 Five Batches & 3 & $10 / 1$ & 95.6 & 1.17 & 1.18 & $\sim 100$ & 60 & Boil \\
\#8 Five Batches & 3 & $10 / 1$ & 97.7 & ND & ND & $\sim 100$ & 60 & Boil \\
\hline
\end{tabular}

consecutive batch experiments (\#5 - \#8) indicate slightly enhanced dissolution relative to single batches. Although the results are limited, the use of higher acid $\left(5 M \mathrm{HNO}_{3}\right)$ at a lower acid to calcine ratio (6 $\mathrm{mL} / \mathrm{g}$ ) in experiment \#6, produced comparable results to the alternate set of dissolution conditions. These results indicate that either of the dissolution procedures are acceptable for this particular type of calcine. It is also important to note that the method of mixing, either by mechanical methods or boiling, has minimal impact on the extent of dissolution. The density of the dissolved calcine solution was fairly consistent under the two different sets of dissolution conditions tested, and was slightly lower than produced by the baseline case. The slight drop in density is attributed to the lower acid and nitrate content of the solution produced by the later dissolution methods. The results from the modified dissolution procedures for Run 74 pilot plant calcine indicate that acceptable dissolution (>95 wt. \% dissolved) can be achieved with a concomitantly lower acid concentration in the dissolver product with modest increases in the dissolution time and temperature. Based on this observation, the dissolution conditions associated with experiment \#8 are proposed as the modified baseline dissolution procedure. Alternatively, the conditions of experiment \#6, followed by dilution with water, also provide acceptable dissolution behavior.

The proposed dissolution process was tested with samples of Run 64 pilot plant calcine to determine the dissolution efficiency under conditions for a similar calcine type. The Run 64 calcine is a blend of zirconium reprocessing raffinate and high sodium tank wastes (a $\mathrm{Zr} / \mathrm{Na}$ blend). As indicated in Table 2, the percent dissolution compared very closely to the Run 74 data, as did the $\left[\mathrm{H}^{+}\right]$and density measurements. This information indicates the proposed baseline dissolution process is amenable to similar types of zirconium calcine.

Table 2. Run 64 (Zr/Na) pilot plant calcine dissolution data.

\begin{tabular}{ccccc}
\hline Dissolution operating parameters: & \multicolumn{4}{l}{$\begin{array}{l}\text { Dissolution time }=1 \text { hour } \\
\text { Acid /Calcine ratio }=10 \mathrm{~mL} \text { acid } / 1 \mathrm{~g} \text { calcine }\end{array}$} \\
& \multicolumn{4}{c}{ Dissolution temperature $=$ boiling $\left(\cong 100{ }^{\circ} \mathrm{C}\right)$} \\
Experiment & Dissolvent & Wt. \% Dissolved & Final $\left[\mathrm{H}^{+}\right](M)$ & Density $(\mathrm{g} / \mathrm{mL})$ \\
\hline \#1 Single Batch & $3 M \mathrm{HNO}_{3}$ & 96.3 & 1.26 & 1.17 \\
\#2 Six Batches & $3 \mathrm{MNO}_{3}$ & 97.0 & 1.18 & 1.16 \\
\hline
\end{tabular}




\section{Run H-4 Radioactive Calcine}

Similar dissolution techniques were utilized to evaluate the dissolution efficiency data for Run H-4 radioactive calcine. Calcine was produced during NWCF campaign H-4 in early 1998 from aqueous wastes in tanks WM-185 and WM-188. Non-radioactive aluminum nitrate (ANN) solutions were blended with the tank waste to dilute the high sodium content and prevent agglomeration of the fluidized calcination bed. According to NWCF Operations [10], the tank feed to the NWCF calciner was switched from WM-188 to WM-185 on 2/20/98. While both calcines produced during the campaign are designated as $\mathrm{H}-4$, they will be referred to as WM-188/ANN and WM-185/ANN for the purposes of this discussion since there are slight compositional differences associated with the two calcines. The elemental composition of the solid calcine can be readily estimated from knowledge of the tank waste composition, ANN blend ratio, and calciner operating parameters [11]. This estimate is indicated in Table 3. Additionally, the composition of the dissolver solution can be estimated from the solid composition, assuming $100 \mathrm{wt}$. \% dissolution and an acid to calcine ratio of $10 \mathrm{~mL} \mathrm{HNO}_{3}$ per $\mathrm{g}$ of calcine. The anticipated composition of the dissolver solution is also indicated in Table 3 for both the WM-185/ANN and WM-188/ANN calcines.

Table 3. Estimated calcine and resulting dissolver solution compositions for $\mathrm{H}-4$ calcines.

\begin{tabular}{|c|c|c|c|c|}
\hline \multirow[b]{2}{*}{ Component } & \multicolumn{2}{|c|}{ WM-185/ANN } & \multicolumn{2}{|c|}{ WM188/ANN } \\
\hline & Calcine (wt. \%) & Diss. Soln. (M) & Calcine (wt. \%) & Diss. Soln. (M) \\
\hline $\mathrm{Na}$ & 7.36 & 0.320 & 6.09 & 0.265 \\
\hline $\mathrm{K}$ & 1.69 & 0.043 & 1.99 & 0.051 \\
\hline $\mathrm{Al}$ & 34.97 & 1.296 & 33.61 & 1.246 \\
\hline $\mathrm{Zr}$ & 0.24 & $2.63 \mathrm{E}-03$ & 0.84 & $9.21 \mathrm{E}-03$ \\
\hline B & 0.52 & 0.048 & 0.4 & 0.037 \\
\hline $\mathrm{F}$ & 0.74 & $1.32 \mathrm{E}-02$ & 2.06 & 0.108 \\
\hline $\mathrm{Ca}$ & 2.48 & 0.062 & 5.22 & 0.130 \\
\hline $\mathrm{Cd}$ & 0.03 & 2.67E-04 & 0.36 & $3.20 \mathrm{E}-03$ \\
\hline $\mathrm{Fe}$ & 0.33 & $5.91 \mathrm{E}-03$ & 1.07 & 0.019 \\
\hline $\mathrm{Cr}$ & 0.057 & $1.10 \mathrm{E}-03$ & 0.239 & $4.60 \mathrm{E}-03$ \\
\hline $\mathrm{Ni}$ & 0.02 & $3.41 \mathrm{E}-04$ & 0.112 & $1.91 \mathrm{E}-03$ \\
\hline $\mathrm{Pb}$ & 0.095 & 4.59E-04 & 0.089 & $4.30 \mathrm{E}-04$ \\
\hline $\mathrm{Hg}$ & $2 \mathrm{E}-04$ & $9.97 \mathrm{E}-07$ & $5 \mathrm{E}-04$ & $2.49 \mathrm{E}-06$ \\
\hline $\mathrm{Mn}$ & 0.252 & $4.59 \mathrm{E}-03$ & --- & --- \\
\hline $\mathrm{U}($ total) & 0.018 & $7.56 \mathrm{E}-05$ & 0.043 & $1.81 \mathrm{E}-04$ \\
\hline $\mathrm{O}$ & 33.99 & N/A & 33.53 & N/A \\
\hline $\mathrm{NO}_{3}$ & 14.88 & 0.240 & 12.94 & 0.209 \\
\hline $\mathrm{Cl}$ & 0.26 & 7.33E-03 & 0.19 & $5.36 \mathrm{E}-03$ \\
\hline $\mathrm{PO}_{4}$ & 0.06 & $6.32 \mathrm{E}-04$ & 0.012 & $1.26 \mathrm{E}-04$ \\
\hline $\mathrm{SO}_{4}$ & 0.84 & $8.74 \mathrm{E}-03$ & 1.2 & $1.25 \mathrm{E}-02$ \\
\hline Radionuclides & $\mathrm{mCi} / \mathrm{g}$ & $\mathrm{dps} / \mathrm{mL}$ & $\mathrm{mCi} / \mathrm{g}$ & $\mathrm{dps} / \mathrm{mL}$ \\
\hline Cs-134 & $1.09 \mathrm{E}-03$ & $4.03 \mathrm{E}+03$ & $5.75 \mathrm{E}-03$ & $2.13 \mathrm{E}+04$ \\
\hline Cs-137 & $2.87 \mathrm{E}-01$ & $1.06 \mathrm{E}+06$ & $1.31 \mathrm{E}+00$ & $4.58 \mathrm{E}+06$ \\
\hline Сo-60 & $1.44 \mathrm{E}-04$ & $5.33 \mathrm{E}+02$ & $1.33 \mathrm{E}-03$ & $4.92 \mathrm{E}+03$ \\
\hline Eu-154 & $9.56 \mathrm{E}-04$ & $3.54 \mathrm{E}+03$ & $6.61 \mathrm{E}-03$ & $2.45 \mathrm{E}+04$ \\
\hline Eu-155 & $3.55 \mathrm{E}-04$ & $1.31 \mathrm{E}+03$ & $2.58 \mathrm{E}-03$ & $9.55 \mathrm{E}+03$ \\
\hline Sr-90 & $2.87 \mathrm{E}-01$ & $1.06 \mathrm{E}+06$ & $9.93 \mathrm{E}-01$ & $3.67 \mathrm{E}+06$ \\
\hline Am-241 & $1.90 \mathrm{E}-04$ & $7.03 E+02$ & $5.10 \mathrm{E}-03$ & $1.89 \mathrm{E}+04$ \\
\hline $\mathrm{Pu}-238$ & $2.05 \mathrm{E}-03$ & $7.59 \mathrm{E}+03$ & $1.35 \mathrm{E}-02$ & $5.01 \mathrm{E}+04$ \\
\hline $\mathrm{Pu}-239$ & $1.74 \mathrm{E}-04$ & $6.44 \mathrm{E}+02$ & $8.59 \mathrm{E}-04$ & $3.18 \mathrm{E}+03$ \\
\hline $\mathrm{Pu}-240$ & $4.95 \mathrm{E}-05$ & $1.83 \mathrm{E}+02$ & $7.58 \mathrm{E}-05$ & $2.81 \mathrm{E}+02$ \\
\hline $\mathrm{Pu}-241$ & $2.19 \mathrm{E}-03$ & $8.12 \mathrm{E}+03$ & $6.83 \mathrm{E}-03$ & $2.53 \mathrm{E}+04$ \\
\hline $\mathrm{Pu}-242$ & $5.90 \mathrm{E}-08$ & $2.18 \mathrm{E}-01$ & $2.17 \mathrm{E}-07$ & $8.05 \mathrm{E}-01$ \\
\hline
\end{tabular}


The high aluminum content, as $\mathrm{Al}_{2} \mathrm{O}_{3}$, of the $\mathrm{H}-4$ calcines results in a higher total weight percentage of oxygen associated with the solid $\mathrm{Al}$ calcine types. Consequently, a higher initial acid concentration is required for the aluminum type calcines than for the $\mathrm{Zr}$ type calcines such as the Run 74 pilot plant material. Assuming that the solid metal oxides in calcine are converted to soluble metal nitrates and water during the dissolution process and that the oxygen accounts for $33.5 \mathrm{wt}$. \% in WM-188/ANN calcine (Table 3):

$M \mathrm{H}^{+}$consumed $=0.335 \mathrm{~g} \mathrm{O} / \mathrm{g}$ calcine $* 1 \mathrm{~mol} \mathrm{O} / 16 \mathrm{~g} \mathrm{O} * 1 \mathrm{~g}$ calcine $/ 10 \mathrm{~mL} * 1000 \mathrm{~mL} / \mathrm{L} * 2 \mathrm{~mol} \mathrm{H} / \mathrm{mol} \mathrm{O}^{+}$ $=4.2 \mathrm{MH}^{+}$consumed

In the case of WM-185/ANN H-4 calcine, the oxygen is slightly higher at $33.99 \mathrm{wt} \%$ and the consumed acid is slightly higher (4.3 $\mathrm{M} \mathrm{H}^{+}$consumed) in accord with the above calculation. For a final acid concentration in the dissolver product of 1 to $1.5 \mathrm{M} \mathrm{H}^{+}$, an initial acid concentration of 5.2 to $5.8 \mathrm{M} \mathrm{HNO}_{3}$ is estimated for the H-4 calcine types.

Dissolution data for $\mathrm{H}-4$ calcine is indicated in Table 4. A batch dissolution experiment was initially performed with WM-188/ANN calcine using $8 \mathrm{MHNO}_{3}$ for preliminary evaluation of dissolution behavior and to prepare a liquid sample for analysis in conjunction with a separate project. This experiment resulted in $93.5 \mathrm{wt}$. \% calcine dissolution and the final acidity of the dissolver product was $4.11 \mathrm{M} \mathrm{H}^{+}$. The acid consumption of $(8 \mathrm{M}-4.1 \mathrm{M}=) 3.9 \mathrm{M} \mathrm{H}^{+}$compares reasonably well with the calculated value of $4.2 M \mathrm{H}^{+}$from above. A second batch dissolution was performed with the WM188/ANN calcine using the baseline dissolution procedure with $5.1 M \mathrm{HNO}_{3}$. The dissolution of $93.3 \mathrm{wt}$. $\%$ dissolved compared favorably with the previous experiment. The $0.98 \mathrm{M} \mathrm{H}^{+}$concentration of the dissolver product compared quite well with the calculated value of $(5.1-4.1=) 1.0 \mathrm{M} \mathrm{H}^{+}$. A third dissolution experiment was performed using four consecutive batch dissolutions of the WM-188/ANN H-4 calcine. In the multi-batch experiment, the dissolver solution was decanted from the UDS remaining in the dissolution vessel and fresh calcine and acid were added with the residual UDS. Dissolution test results indicate $98.2 \mathrm{wt}$ \% of the initial WM-188/ANN H-4 calcine mass dissolved using 5.9 $M$ nitric acid. The higher percentage dissolved, relative to that observed in the single batch dissolutions, is consistent with results for the pilot plant calcines and indicate the benefit of using multiple batches. Finally, a single batch dissolution was performed with a sample of the WM-185/ANN H-4 calcine using 5.1 $M \mathrm{HNO}_{3}$. The 88.9 wt. \% dissolved was slightly lower than observed for the single batch dissolution of the WM-188/ANN calcine. The final acid concentration of $1.28 \mathrm{M} \mathrm{H}^{+}$in the dissolver product indicates dissolution was somewhat incomplete compared with the above acid consumption estimates. However, this anomaly cannot be explained without the benefit of additional experiments, since the discrepancy could also easily be attributed to experimental error. An additional 200g of the WM-185/ANN H-4 calcine is available for further dissolution testing, including consecutive and single batch dissolutions. Finally, it should be noted that the dissolution data from the H-4 radioactive coincide reasonably well with the pilot plant calcine dissolution data and indicate the baseline procedure (with modification of the initial acid concentration) is amenable to the calcine produced in NWCF campaign H-4.

Table 4. Campaign H-4 radioactive calcine dissolution data.

\begin{tabular}{|c|c|c|c|}
\hline Dissolution operatin & $\begin{array}{r}\text { s: Dissolution } \\
\text { Dissolution } \\
\text { Acid /Calci }\end{array}$ & $\begin{array}{l}\sim 100^{\circ} \mathrm{C} \\
\mathrm{ur} \\
\mathrm{mL} \text { acid/ } 1 \mathrm{~g} \text { calc }\end{array}$ & \\
\hline Calcine Type & Dissolvent & Wt. \% Dissolved & Final $\left[\mathrm{H}^{+}\right](M)$ \\
\hline WM-188/ANN ${ }^{1}$ & $8 \mathrm{MHNO}_{3}$ & 93.5 & 4.11 \\
\hline WM-188/ANN ${ }^{1}$ & $5.1 \mathrm{MHNO}_{3}$ & 93.3 & 0.98 \\
\hline WM-188/ANN ${ }^{2}$ & $5.9 \mathrm{MHNO}_{3}$ & 98.2 & 1.92 \\
\hline WM-185/ANN ${ }^{1}$ & $5.1 M_{\mathrm{HNO}_{3}}$ & 88.9 & 1.28 \\
\hline
\end{tabular}


The dissolver solutions from some of the WM-188/ANN calcine dissolutions were submitted for analytical analysis. It is of interest to compare the analytical results with the estimated results from Table 3 for the dissolved calcine solution, as indicated in Table 5. It is noteworthy that for most analytes (with the exceptions of $\mathrm{Hg}$, Cs-137, and Eu-154), the results are consistently lower than the estimated concentration in the dissolved calcine solutions. The concentrations of the major components $(\mathrm{Na}, \mathrm{Al}$, and Ca) compare reasonably, within $80 \%$, of the estimated results. The comparison between estimated and analytical results is quite reasonable given the uncertainties and assumptions associated with the data.

Table 5. Comparison of estimated and analytical results for dissolved WM-188/ANN calcine.

\begin{tabular}{|c|c|c|c|c|c|}
\hline Component & Estimated (M) & Analytical (M) & Radionuclides & Estimated (dps/mL) & Analytical (dps/mL) \\
\hline $\mathrm{Na}$ & 0.265 & $0.217^{1,2}$ & Cs-134 & $2.13 \mathrm{E}+04$ & $9.26 \mathrm{E}+03^{2,3}$ \\
\hline $\mathrm{K}$ & 0.051 & $0.036^{1,2}$ & Cs-137 & $4.85 \mathrm{E}+06$ & $5.87 \mathrm{E}+06^{1,2,3}$ \\
\hline $\mathrm{Al}$ & 1.246 & $1.058^{1,2}$ & Co-60 & $4.92 \mathrm{E}+03$ & $2.92 \mathrm{E}+03^{2,3}$ \\
\hline $\mathrm{Zr}$ & $9.21 \mathrm{E}-03$ & $3.57 \mathrm{E}-03^{1}$ & Eu-154 & $2.45 E+04$ & $3.25 \mathrm{E}+04^{2,3}$ \\
\hline $\mathrm{B}$ & 0.037 & $0.046^{2}$ & Eu-155 & $9.55 E+03$ & $5.08 \mathrm{E}+03^{3}$ \\
\hline $\mathrm{F}$ & $1.08 \mathrm{E}-01$ & $0.023^{2}$ & Sr-90 & $3.67 \mathrm{E}+06$ & $8.07 \mathrm{E}+05^{2}$ \\
\hline $\mathrm{Ca}$ & 0.130 & $0.124^{1,2}$ & Am-241 & $1.89 \mathrm{E}+04$ & $6.01 E+02^{2}$ \\
\hline $\mathrm{Fe}$ & $1.92 \mathrm{E}-02$ & $1.11 \mathrm{E}-02^{1,2}$ & $\mathrm{Pu}-238$ & $5.01 \mathrm{E}+04$ & $4.27 \mathrm{E}+03^{2}$ \\
\hline $\mathrm{Cr}$ & $4.60 \mathrm{E}-03$ & $4.05 \mathrm{E}-03^{1}$ & $\mathrm{Pu}-239$ & $3.18 \mathrm{E}+03$ & $5.15 \mathrm{E}+02^{2}$ \\
\hline $\mathrm{Ni}$ & $1.91 \mathrm{E}-03$ & $1.87 \mathrm{E}-03^{1}$ & Tc-99 & --- & $2.69 \mathrm{E}+02^{2}$ \\
\hline $\mathrm{Pb}$ & 4.30E-04 & $2.49 \mathrm{E}-04^{1,2}$ & Gross $\alpha$ & --- & $5.55 \mathrm{E}+03^{2}$ \\
\hline $\mathrm{Hg}$ & 2.49E-06 & $2.51 \mathrm{E}-05^{1,2}$ & Gross $\beta$ & --- & $2.48 \mathrm{E}+06^{2}$ \\
\hline Cs (Total) & --- & $5.01 \mathrm{E}-05^{1,3}$ & & & \\
\hline Sr (Total) & --- & $1.03 \mathrm{E}-04^{1,3}$ & & & \\
\hline $\mathrm{Cl}$ & $5.36 \mathrm{E}-03$ & $<1.03 \mathrm{E}-03^{1,2}$ & & & \\
\hline
\end{tabular}

${ }^{1}$ Analytical Log \#98-0323-9

${ }^{2}$ Analytical Log \#98-0609-2

${ }^{3}$ Analytical Log \#98-0318-2

A small sample of the UDS was removed from the RAL hot cell for analysis by X-Ray Diffraction (XRD) and Scanning Electron Microscope (SEM) analytical methods. Sample analyses were associated with analytical log \#98-0326-2. Initially, an attempt was made to remove a 0.1 gram sample of the WM188/ANN UDS from the hot cell. Due to the intense $\beta$ activity of the sample, this quantity of material could not be removed for analysis. Successful removal of a UDS sample was accomplished by placing a minute quantity (several small particles) of the material on the end of a cotton swab. XRD and SEM analyses was performed on these particles, although the sample size precludes meaningful results from the standpoint of both detection limits and obtaining a representative sample of the bulk UDS from the dissolution experiments. The results of the $\mathrm{XRD}$ analysis indicated calcium stabilized zirconium $\left(\mathrm{Ca}_{0.15} \mathrm{Zr}_{0.85} \mathrm{O}_{1.85}\right)$ was present and $\mathrm{Ca}_{4.5} \mathrm{Si}_{6} \mathrm{O}_{15}(\mathrm{OH})_{3}$ was possibly present. The presence of calcium stabilized zirconium is consistent with UDS results from dissolution of pilot plant $\mathrm{Zr}$ calcine types. It should be noted that the XRD results are somewhat uncertain since the sample was mostly amorphous or the sample size was too small for a clear crystal pattern. The SEM results indicated that $\mathrm{Al}, \mathrm{Zr}$, and $\mathrm{O}$ were the major elements detected. Silicon, K, Ca, Mn, and Fe were also detected as minor constituents.

Future work is required, and planned, to better evaluate and characterize calcine UDS. These evaluations will include chemical analysis and particle size distribution of the residual UDS. 


\section{Parametric Dissolution Studies}

A series of statistically designed experiments were conducted in accord with Box et al. [12] and were a simple $2^{\mathrm{n}}$ factorial design. These experiments were performed to evaluate the effects and interactions of three experimental variables on the weight percent dissolution of Run 74 pilot plant calcine. The primary purpose of the statistical experiments was to evaluate the effect of mixing on the calcine dissolution process relative to other important parameters. The three variables studied were:

- Acid-to-calcine ratio

- Temperature

- Mixing rate

The dissolution time and acid concentration were held constant for this series of experiments. Previous results from statistically designed experiments with pilot plant calcines indicated the acid to calcine ratio and temperature were the most prominent variables affecting dissolution relative to nitric acid concentration and dissolution time [2].

In accord with Box [14], standard "sign" nomenclature was used to define variable ranges. Table 6 lists the variables, associated sign, and ranges used in the statistical experiments. The ranges selected for the process variables were selected based on results of previous, similar type studies [2]. Each dissolution experiment was performed in duplicate.

Table 6. Sign nomenclature including variable parameters for statistical experiment.

\begin{tabular}{cccc}
\hline Sign & Acid/Calcine Ratio & Temperature $\left({ }^{\circ} \mathrm{C}\right)$ & Mixing $(\mathrm{rpm})$ \\
\hline+ & $20 \mathrm{~mL} / 1$ gram & 90 & 500 \\
- & $10 \mathrm{~mL} / 1$ gram & 60 & 0 \\
\hline
\end{tabular}

The measured response for each set of conditions is the wt. \% of calcine dissolved. The results of these experiments are incorporated in Table 7, which includes the sign nomenclature for the different process variables. As anticipated, less of the material was dissolved when process variables were at lowest values (experiment \#1), and more of the material was dissolved when the variables were at maximum values (experiment \#8). Note that experiment \#8 conforms to the new baseline dissolution procedure developed with Run 74 pilot plant calcine (vide supra). The result of 97.55 wt. \% dissolved in experiment \#8 agrees quite well with earlier experimental results presented in Table 1 for Run 74 calcine.

Table 7. Table of signs illustrating results of dissolution experiments with Run 74 pilot plant calcine.

\begin{tabular}{ccccc}
\hline $\begin{array}{c}\text { Experiment } \\
\text { Number }^{a}\end{array}$ & $\begin{array}{c}\text { Acid/Calcine } \\
\text { Ratio }\end{array}$ & Temperature & $\begin{array}{c}\text { Mixing } \\
\text { Rate }\end{array}$ & $\begin{array}{c}\text { Wt. \% } \\
\text { Dissolved }\end{array}$ \\
\hline $1^{(1)}$ & - & - & - & 37.25 \\
$2^{(4)}$ & + & - & - & 61.55 \\
$3^{(3)}$ & - & + & - & 87.60 \\
$4^{(5)}$ & + & + & - & 96.40 \\
$5^{(2)}$ & - & - & + & 61.45 \\
$6^{(6)}$ & + & + & + & 65.55 \\
$7^{(8)}$ & - & + & + & 84.15 \\
$8^{(7)}$ & + & + & 97.55 \\
\hline
\end{tabular}

${ }^{\mathrm{a}}$ Superscript denotes the order in which experiments were performed. 
The fundamental purpose for performing a statistically designed experiment is to establish or rank the effects and interactions of the process variables on a measured response, in this case weight percent calcine dissolved. An effect/interaction analysis was performed utilizing Yates Algorithm [12] and standard errors were calculated in accord with Box et al. [12]. The results of the interaction analysis are indicated in Table 8.

Table 8. Statistical analysis of process variable effects on dissolution of Run 74 calcine.

\begin{tabular}{ccc}
\hline Variable & $\begin{array}{c}\text { Effect on Wt. \% Dissolved } \\
\pm \text { Standard Error }\end{array}$ & Effect \\
\hline Overall Average & $73.9 \pm 0.11$ & Average \\
\hline Acid/Calcine Ratio & $12.65 \pm 2.1$ & Main Effects \\
Temperature & $34.98 \pm 2.1$ & \\
Mixing & $6.475 \pm 2.1$ & Two-factor Interactions \\
\hline Acid/Calcine Ratio:Temperature & $-1.55 \pm 2.1$ & \\
Acid/Calcine Ratio:Mixing & $-3.9 \pm 2.1$ & Three-Factor Interactions \\
Temperature:Mixing & $-7.63 \pm 2.1$ & \\
\hline Acid/Calcine:Temperature:Mixing & $6.2 \pm 2.1$ & \\
\hline
\end{tabular}

The overall average in Table 8 reflects the average amount of Run 74 calcine dissolved in all eight experiments. A comparison of the effect estimates with their standard errors suggests the acid to calcine ratio/temperature and acid to calcine ratio/mixing (two-factor) and the three-factor interactions are negligible and likely result from experimental noise. The main effects are a measure of the average impact each process variable independently has on the dissolution process. For example, a change in the acid/calcine ratio from $10 \mathrm{~mL} / \mathrm{g} \mathrm{(-)}$ to $20 \mathrm{~mL} / \mathrm{g}(+)$ will have an average effect of increasing the amount of Run 74 calcine dissolved by $+12.65 \mathrm{wt}$. \%. The two- and three-factor interactions provide an indication of multiple variable effects on the weight percent dissolved. It is of interest to note that the temperature/ mixing interaction is of the same order of magnitude as the mixing main effect. The magnitude of these effects indicates that mixing plays a minimal role in the dissolution process.

The results from the Yates analysis indicate that the mixing rate is the least important factor (of the variables examined) on calcine dissolution. The temperature variable provides the most significant impact on the measured response, wt. \% dissolution. The order of importance for the three variables studied is:

Temperature $>$ Acid/Calcine Ratio $>$ Mixing

Previous results from statistically designed experiments on different pilot plant calcines (Run 17, a $\mathrm{Zr} / \mathrm{Na}$ blend and Run 20, a $\mathrm{Al} / \mathrm{Zr} / \mathrm{Na}$ blend) indicated the importance of the process variables studied (acid/calcine ratio, time, temperature, and acid concentration) was [2]:

\section{Acid/Calcine Ratio $>$ Temperature $>\mathrm{HNO}_{3}$ Concentration $>$ Dissolution Time}

While the two most prominent variables of the acid/calcine ratio and temperature were consistent for both data sets, the relative importance was reversed. This nuance is possibly attributed to the different calcine types studied and/or the much larger variation in the ranges of process variables used in the previous study [2].

This information will be beneficial for use in future dissolution design studies, since the results indicate $>95$ wt. $\%$ of the calcine can be dissolved without the aid of mechanical agitation. Cost reduction associated with repair or replacement of mechanical stirring devices due to failures contributed to corrosion originating from $\mathrm{HNO}_{3}$ acid use can be realized. Furthermore, the effects of temperature and the ratio of acid to calcine will predominate the dissolution process. 


\section{CONCLUSIONS AND RECOMMENDATIONS}

\section{Conclusions}

\section{Pilot Plant Calcine}

Greater than 95 wt. \% dissolution of $\mathrm{Zr}$ type calcines can be achieved using $3 M$ nitric acid. The acid concentration in the final solution is reduced to $\sim 1.2 \mathrm{M} \mathrm{H}^{+}$. This solution provides a more suitable feed stream for the proposed solvent extraction unit operations, particularly the TRUEX process. The following conditions are required to obtain >95 wt. \% dissolution for Run 64 and Run $74 \mathrm{Zr}$ type pilot plant calcines and define the baseline dissolution procedure to be used in continued design studies associated with $\mathrm{Zr}$ calcine types:

- Maximum nitric acid concentration of $3 \mathrm{MHNO}_{3}$

- Minimum acid to calcine ratio of $10 \mathrm{ml}$ acid/1 gram calcine

- Minimum temperature of $>95^{\circ} \mathrm{C}$

- Minimum dissolution time of 1 hour

\section{Run H-4 Radioactive Calcine}

The baseline dissolution procedure is amenable to this type of calcine, provided the nitric acid concentration is adjusted (to $\sim 5.2 \mathrm{M} \mathrm{HNO}_{3}$ ) to insure stoichiometric quantities of acid are available to compensate for oxygen content in the different calcine. This result indicates the importance of adjusting the initial nitric acid concentration depending on the type of calcine being dissolved. Continued work with additional types of radioactive calcines is required for verification of the dissolution process.

\section{Parametric Dissolution Studies}

Based on results obtained from the interaction analysis, the effect of the studied process variables on the amount of Run 74 pilot plant calcine dissolved decreases according to the order:

\section{Temperature > Acid/Calcine Ratio > Mixing Rate}

Furthermore, mixing does not significantly contribute the amount of Run 74 pilot plant calcine dissolved. This result, in conjunction with previous interaction analyses with different pilot plant calcine types indicates temperature and the acid/calcine ratio are the significant process variables associated with calcine dissolution.

\section{Recommendations}

It is imperative that the dissolution process be studied on numerous types of radioactive calcines. Work is currently in progress to obtain samples of radioactive calcine retrieved several years ago from bin set \#2 (Zr and Al types) and currently stored in INTEC's $601 \mathrm{D}$-cell for dissolution and chemical analysis. In addition, samples of Fluorinel calcine and H-3 calcine have been identified for dissolution and analysis studies. Aside from evaluating the dissolution behavior of actual calcines, analysis of the dissolved solution and physical and chemical characteristics of residual UDS are required. Due to the lack of a suitable pilot plant $\mathrm{Al}$ calcine for development work, the $10 \mathrm{~cm}$ pilot plant calciner recently produced $\sim 10$ $\mathrm{kg}$ of Al type calcine. Secondly, a small sample, $<1 \mathrm{~kg}$, of non-radioactive WCF startup bed calcine was obtained. Dissolution studies will continue with these calcine surrogates. It is mandatory to obtain and study the dissolution behavior of actual Al calcine (the D-cell material) in order to evaluate the applicability of the non-radioactive materials for development efforts. 


\section{REFERENCES}

1. Berreth, J. R., "Inventories and Properties of ICPP Calcined High-Level Waste", report WINCO1050, February 1988.

2. Herbst, R. S., et al., "Experimental Results: Pilot Plant Calcine Dissolution and Liquid Feed Stability", report INEL-95/0097, February 1995.

3. Newby, B. J., et al., “Calcination Flowsheet Development”, report ICP-1163, October 1998.

4. Staples, B. A. et al., "Properties of Radioactive Calcine Retrieved From the Second Calcined Solids Storage Facility at ICPP”, ICP-1189, March 1997.

5. Paige, B. E., "Leachability of Alumina Calcine Produced in the Idaho Waste Calcining Facility", report IN-1011, July 1966.

6. Brewer, K. N. , et al., "Dissolution of Two NWCF Calcines: Extent of Dissolution and Characterization of Undissolved Solids", INEEL/EXT-95-0098, February 1995.

7. Brewer, K. N., et al., "Actinide Partitioning From Actual ICPP Dissolved Zirconium Calcine Using the TRUEX Solvent”, report INEEL/EXT-95-0225, May 1995.

8. Brewer, K. N., et al., "Elimination of Phosphate and Zirconium in the High Activity Fraction Resulting From TRUEX Partitioning of ICPP Zirconium Calcines", report INEEL/EXT-97-00836, July 1997.

9. Herbst, R. S., et al., "Baseline TRUEX Flowsheet Development for the Removal of Actinides from Dissolved INTEC Calcine Using Centrifugal Contactors", report INEEL/EXT-98-00833, August 1998.

10. Law, J. P., NWCF Operations, personal communication, June 8, 1998.

11. O’Brien, G. H., Staiger, M. D., unpublished data, 1998.

12. Box, G. E. P., Hunter, W. G. and Hunter, J. S., Statistics For Experimenters, An Introduction to Design, Data Analysis, and Model Building, Chapters 9-11, John Wiley \& Sons, New York, NY, 1978. 
Appendix A

Experimental Data 
Table A-1. Run 74 pilot plant calcine (single batches).

\begin{tabular}{ccccc}
\hline Dissolvent & Calcine wt. & UDS wt. & Time (hrs) & \% Dissolution \\
\hline $3 \mathrm{MNO}_{3}$ & $5.00009 \mathrm{~g}$ & $0.43886 \mathrm{~g}$ & 1 & 91.0 \\
$3 \mathrm{MHNO}_{3}$ & $5.00069 \mathrm{~g}$ & $0.31806 \mathrm{~g}$ & 2 & 93.6 \\
$3 \mathrm{M} \mathrm{HNO}_{3}$ & $5.00035 \mathrm{~g}$ & $0.21600 \mathrm{~g}$ & 6 & 95.7 \\
\hline
\end{tabular}

Note: The above experiments were all performed using the following conditions: dissolvent volume $=50 \mathrm{mLs}$, Temperature $\geq 95^{\circ} \mathrm{C}$, aggressive mixing with a stirbar.

Table A-2. Run 74 pilot plant calcine (successive batches).

\begin{tabular}{lcllclll}
\hline Dissolvent & \# Batches & $\begin{array}{l}\text { Weight } \\
\text { Calcine }(\mathrm{g})\end{array}$ & $\begin{array}{l}\text { Dissolvent } \\
\text { Volume }(\mathrm{mL})\end{array}$ & $\begin{array}{l}\text { Time } \\
(\mathrm{hrs})\end{array}$ & $\begin{array}{l}\text { Mixing } \\
\text { Method }\end{array}$ & $\begin{array}{l}\text { Weight } \\
\text { UDS }(\mathrm{g})\end{array}$ & $\begin{array}{l}\text { Weight\% } \\
\text { Dissolution }\end{array}$ \\
\hline $5 \mathrm{MHNO}_{3}$ & 2 & 10.00088 & 100 & 0.5 & Stirbar & 0.25322 & 97.5 \\
$5 \mathrm{MHNO}_{3}$ & 4 & 20.00166 & 200 & 0.5 & Stirbar & 0.28793 & 98.6 \\
$5 \mathrm{MHNO}_{3}$ & 6 & 30.00354 & 300 & 0.5 & Stirbar & 0.41465 & 98.6 \\
$5 \mathrm{MHNO}_{3}$ & 12 & 60.00158 & 600 & 0.5 & Stirbar & 0.35845 & 99.4 \\
$3 \mathrm{MHNO}_{3}$ & 5 & 5.00078 & 50 & 1 & Stirbar & 0.24864 & 95.0 \\
$5 \mathrm{MHNO}_{3}$ & 5 & 4.99986 & 30 & 1 & Stirbar & 0.16807 & 96.6 \\
$3 \mathrm{MHNO}_{3}$ & 5 & 5.00140 & 50 & 1 & Boiling & 0.21931 & 95.6 \\
$3 \mathrm{MHNO}_{3}$ & 5 & 5.00097 & 30 & 1 & Boiling & 0.11652 & 97.7 \\
\hline
\end{tabular}

Note: The above experiments were all performed using at a temperature $\geq 95^{\circ} \mathrm{C}$.

Table A-3. Run 64 pilot plant calcine.

\begin{tabular}{llccllll}
\hline & $\begin{array}{l}\text { Weight } \\
\text { Calcine }(\mathrm{g})\end{array}$ & $\begin{array}{l}\text { Volume } \\
\text { Dissolvent }(\mathrm{mL})\end{array}$ & $\begin{array}{l}\text { Time } \\
(\mathrm{hrs})\end{array}$ & $\begin{array}{l}\text { Temp } \\
\left({ }^{\circ} \mathrm{C}\right)\end{array}$ & $\begin{array}{l}\text { Mixing } \\
\text { Method }\end{array}$ & $\begin{array}{l}\text { Weight } \\
\text { UDS }(\mathrm{g})\end{array}$ & $\begin{array}{l}\text { Weight } \% \\
\text { Dissolution }\end{array}$ \\
\hline $3 \mathrm{MNO}_{3}$ & 5.00045 & $50^{1}$ & 1 & $>100$ & Stirbar & 0.18278 & 96.3 \\
\hline $3 \mathrm{HNO}_{3}$ & 2000.014 & $2000^{2}$ & 1 & $>95$ & Stirbar & 60.6959 & 97.0 \\
\hline $\begin{array}{l}{ }^{1} \text { Single batch } \\
{ }^{2} \text { Six successive batches }\end{array}$ & & & & & & & \\
\hline
\end{tabular}

Table A-4. $\left[\mathrm{H}^{+}\right]$and density measurements for various dissolved calcine solutions.

\begin{tabular}{llcll}
\hline Calcine Type & Dissolvent & \# Batches & {$\left[\mathrm{H}^{+}\right](M)$} & Density $(\mathrm{g} / \mathrm{mL})$ \\
\hline Run 74 & $3 \mathrm{MHNO}_{3}$ & 1 & 1.21 & N/A \\
Run 74 & $3 \mathrm{MHNO}_{3}$ & 5 & 1.17 & 1.18 \\
Run 74 & $5 \mathrm{MHNO}_{3}$ & 5 & 1.17 & 1.11 \\
Run 74 & $3 \mathrm{MNO}_{3}$ & 1 & 1.10 & 1.17 \\
Run 64 & $3 \mathrm{MHNO}_{3}$ & 1 & 1.26 & 1.17 \\
Run 64 & $3 \mathrm{MHNO}_{3}$ & 6 & 1.18 & 1.16 \\
Run 64 & $3 \mathrm{MHNO}_{3}$ & 6 & 1.17 & 1.2 \\
\hline
\end{tabular}

\footnotetext{
${ }^{1}$ Experiment with an acid/calcine ratio of $1 \mathrm{~g} / 6 \mathrm{mLs}$, the final dissolved solutions were diluted up to a final volume equivalent of $1 \mathrm{~g} / 10 \mathrm{mLs}$ with deionized water before $\left[\mathrm{H}^{+}\right]$and density measurements were determined.
} 
Table A-5. Dissolution data for actual H-4 NWCF calcine.

\begin{tabular}{lllllllll}
\hline & $\begin{array}{l}\text { Weight } \\
\text { Dissolvent }\end{array}$ & Calcine $(\mathrm{g})$ & $\begin{array}{l}\text { Weight } \\
\text { UDS }(\mathrm{g})\end{array}$ & $\begin{array}{l}\text { Volume } \\
\text { Dissolvent }(\mathrm{mL})\end{array}$ & $\begin{array}{l}\text { Time } \\
(\mathrm{min})\end{array}$ & $\begin{array}{l}\text { Temp } \\
\left({ }^{\circ} \mathrm{C}\right)\end{array}$ & $\begin{array}{l}\text { Mixing } \\
\text { Method }\end{array}$ & $\begin{array}{l}\text { Weight \% } \\
\text { Dissolutior }\end{array}$ \\
\hline $5.9 \mathrm{MHNO}_{3}$ & $190.83^{1}$ & 3.541 & 1900 & 90 & $\sim 100$ & Stirbar & $\left.9 \mathrm{H}^{+}\right]$ \\
$5.1 \mathrm{M} \mathrm{HNO}_{3}$ & $39.151^{1}$ & 2.610 & 392 & 90 & $\sim 100$ & Stirbar & 93.3 & 1.92 \\
$8 \mathrm{MNO}_{3}$ & $28.956^{1}$ & 1.893 & 290 & 90 & $\sim 100$ & Stirbar & 93.5 & 4.11 \\
$5.1 \mathrm{M} \mathrm{HNO}_{3}$ & $20.181^{2}$ & 2.231 & 201 & 60 & $\sim 100$ & Stirbar & 88.9 & 1.28 \\
\hline
\end{tabular}

${ }^{1}$ WM-188/ANN H-4 calcine.

${ }^{2}$ WM-185/ANN H-4 calcine.

Table A-6. Weight \% dissolution for parametric dissolution study variables.

\begin{tabular}{lllllll}
\hline \multirow{2}{*}{ Process Variables } & \multicolumn{2}{c}{ Set 1 } & \multicolumn{2}{c}{ Set 2 } & \multicolumn{2}{c}{ Average } \\
\cline { 2 - 7 } & $0 \mathrm{rpm}$ & $500 \mathrm{rpm}$ & $0 \mathrm{rpm}$ & $500 \mathrm{rpm}$ & $0 \mathrm{rpm}$ & $500 \mathrm{rpm}$ \\
\hline 30 grams: $60^{\circ} \mathrm{C}$ & 37.1 & 55.8 & 37.4 & 67.1 & 37.25 & 61.45 \\
15 grams: $60^{\circ} \mathrm{C}$ & 59.6 & 71.4 & 63.5 & 59.7 & 61.55 & 65.55 \\
30 grams: $90^{\circ} \mathrm{C}$ & 86.5 & 85.4 & 88.7 & 82.9 & 87.6 & 84.15 \\
15 grams: $90^{\circ} \mathrm{C}$ & 96.2 & 96.8 & 96.6 & 98.3 & 96.4 & 97.55 \\
\hline
\end{tabular}

